\title{
Franchise fairs: A relevant signal in franchise choice in social activity
}

\author{
Leonardo Martin Mastrangelo', Esther Calderon-Monge ${ }^{2}$, Pilar Huerta-Zavala²
}

ABSTRACT

\begin{abstract}
Potential franchisees encounter difficulties in gaining knowledge about a franchise before embarking on their first start-up venture. For this reason, it is necessary to research which information signals help potential franchisees choose the franchise chains with which they wish to enter into business. Working within the framework of signaling theory, this study's aim is to analyze the relationship between franchise choice and brand, price and participation in franchise fairs. The dynamic signaling model deployed to achieve the study's aim draws on panel data methodology. This methodology allows us to analyze franchise chains over the period in which their parent franchises were using signaling to reveal information about their quality to potential franchisees. The results show that franchise fairs and up-front entry fees influence franchisee's decisions. Therefore, it is concluded that potential franchisees prefer to garner information directly from franchise fairs, as opposed to heeding the other signals under study, and that when macroeconomic variables are exerting a strong influence on potential franchisees, up-front entry fees also constitute a signal that they consider. Finally, the managerial implications of the study are that franchise chains seeking franchisees should participate in franchise fairs to ensure that they are among the chosen franchises. Additionally, a franchisor should appropriately manage up-front entry fees as a signal, especially during periods of economic turmoil and recession.
\end{abstract}

KEY WORDS: $\quad$ Entrepreneurship; signals; price; franchising; GMM; franchise fairs

JEL Classification: M13, M31

${ }^{1}$ Faculty of Economy, University of València, Spain; ${ }^{2}$ Faculty of Economics and Business Studies, University of Burgos, Spain

\section{Introduction}

In recent years, franchises in Spain have been operating in an economy reeling from the effects of recession.

This economic backdrop has forced franchises to move with the times, requiring them to demonstrate great flexibility and creativity. During this period, so-called low-cost franchises have surfaced that strive to limit

Correspondence concerning this article should be addressed to: Leonardo Martin Mastrangelo, University of València, Faculty of Economy, Campus de los Naranjos, 46021 Valencia, Spain. E-mail: leomastrangelo@hotmail.es investment, which is revolutionizing existing business concepts. Franchises have also launched new products and services to adapt to consumers' changing habits. Evidence of franchises' capacity to adjust in such a precarious environment can be observed in the high number of attendees at Spain's most well-established franchise fairs, such as SIF\&Co and ExpoFranquicia. In 2012, these events welcomed 23,000 visitors through their doors, boasting the participation of approximately 500 franchise brands. Furthermore, of these 23,000 visitors, almost $80 \%$ attended these fairs with a view to accessing business opportunities by means of a fran- 
chise agreement. This reflects the role of franchising as an alternative for potential franchisees that provides a model not only for product distribution but also for starting up a new business. Accordingly, in 2012, the opportunity entrepreneurship rate (ventures that exploit a specific business opportunity) was $72.3 \%$ (Xavier, Kelley, Kew, Herrington, \& Vorderwülbecke, 2012).

Budding entrepreneurs habitually view franchising as a chance to run a business, as franchising offers a guarantee of success, value added-as a business that has been tried and tested by the franchisor-an established brand image, initial and on-going training, economies of scale, and the so forth that permit the entrepreneur to develop and mature in a competitive environment.

The aim of the current study is to analyze the relationship between franchise choice and brand, price and franchise participation in franchise fairs. We test the hypotheses that appear in Section 2 using data from a database of 166 franchise chains that were operating across three sectors in Spain between 2006 and 2011. The dynamic signaling model deployed to achieve the above aim draws on panel data methodology. This methodology allows us to analyze franchise establishments over the period in which their parent franchises were using signaling to reveal information about their quality to potential franchisees. The results from the estimation of the model show that potential franchisees looking to start a business under a franchise agreement deem franchise fairs to be a signal that directly provides pertinent information about franchise chains.

This paper has five sections. Following the introduction, Section 2 presents a brief summary of signaling theory as a basis for later positing our hypotheses. Section 3 describes the study sample and the variables in the model, while Section 4 defines and estimates the model. Finally, Section 5 lays out the results and conclusions of the study.

\section{Theoretical framework and hypotheses}

In franchising, broadly understood as an exchange relationship, a potential franchisee encounters difficulties in gaining knowledge about the franchise before embarking on a relationship, giving rise to information asymmetries. We therefore pose the fol- lowing research question: which information signals help potential franchisees resolve problems of information asymmetry with respect to the franchisor? The economics literature presents signaling theory as a strategy for potential franchisees to gather knowledge about franchise chains (Dant \& Kaufmann, 2003). The majority of signaling models include the variable of quality (Janney \& Folta, 2006). Potential franchisees choose chains with a certain level of quality, and this quality may be determined by signals such as brand recognition of the franchise (Weaven \& Frazer, 2006) and price (Shane, Shankar \& Aravindakshan, 2006; Wu, 1999) specifically, up-front entry fees, royalties, and investment. Additionally, quality may be perceived through visits to franchise fairs, which constitute an important communication channel that links the business to its current and potential clients (Baena \& Cerviño, 2012).

\subsection{Brand equity of a franchise}

A readily accessible indirect indication of a commercial chain's current brand equity is longevity (Dant \& Kaufmann, 2003). Longevity refers to the number of years a franchise has been operating in the marketplace (Mariz \& García, 2009). Potential franchisees seek franchises with renowned brands because this attribute is a guarantee of future success. Better brand recognition increases a business's appeal, as it attracts clients, aids the company in differentiating itself from the competition, and reduces potential franchisees' costs of searching for information about the chain (Baena \& Cerviño, 2012). Social venture franchising is liable to lead to increased selection costs because franchisees are organizations rather than individuals, and franchisees are assessed on their ability to achieve both social and commercial objectives (Tracey \& Jarvis, 2007). Therefore, franchises with greater longevity have greater brand equity, which encourages potential franchisees to choose the franchise chain. We therefore posit the following hypothesis.

HI: Potential franchisees' choice of franchise is positively related to franchise brand equity.

\subsection{Franchisees' initial investment}

Meeting franchisees' expectations-in particular, those regarding the quality of a franchised outlet's daily operations and franchisees' perceptions of re- 
covering their initial investment (Grace \& Weaven, 2011)_causes the perceived risk of an investment when opening a franchise to fall dramatically and encourages future investment in the franchise. Thus, franchises that demand large amounts of initial investment will have fewer franchised outlets than other franchises that demand less initial capital from their franchisees (Shane et al., 2006). We therefore posit the following hypothesis.

H2: Potential franchisees' choice of franchise is negatively related to the initial investment demanded by the franchisor.

\subsection{Franchises' up-front entry fees}

Up-front entry fees act as a mechanism in a chain's quality control procedures. Therefore, the reputation of a franchise chain offers an alternative mechanism for attracting potential franchisees, with the franchisor able to set high up-front entry fees to attract potential franchisees (Shane et al., 2006). This argument leads to the following hypothesis.

H3: Potential franchisees' choice of franchise is positively related to up-front entry fees.

\subsection{Franchise royalties}

Franchisors justify charging royalties to franchisees on the basis of their commitment to transferring concepts and know-how and to promoting the franchise network (Fadairo, 2013). As stated by signaling theory, potential franchisees are more disposed to open an outlet with a franchise that demands higher royalties. Numerous scholars find a positive relation between the propensity to franchise and royalties (Shane et al., 2006). We therefore posit the following hypothesis.

H4: Potential franchisees' choice of franchise is positively related to royalties.

\subsection{Franchises' participation in franchise fairs}

Franchise fairs are an important communication channel (Blythe, 2010; Guilloux, Gauzente, Kalika \& Dubost, 2004) in the sense that they act as a showcase for different business concepts, offer a meeting place for brands and investors, and serve as a platform for networking and obtaining information about the sector and new trends. Potential franchisees attend franchise fairs because they believe them to be an important medium for gathering information about new franchise business opportunities (Bennett, Frazer, \& Weaven, 2010). The participation of franchises in franchise fairs is a key factor in introducing the business concept to and establishing a direct relationship with potential franchisees, which is impossible to do via the traditional press, brochures, and the like. The implication is that social franchising is more effective when franchisees are given a higher degree of autonomy (Tracey \& Jarvis, 2007). Therefore, direct marketing is highly effective in attracting new franchisees (Perrigot, Basset, \& Cliquet, 2011). This argument leads to the following hypothesis.

H5: Potential franchisees' choice of franchise is positively related to franchises' participation in franchise fairs.

\section{Research}

The data come from the Spanish Association of Franchisors and the consultancy Tormo and Associates. The sample consists of non-aggregated data for 166 franchise chains that were operative in Spain between 2006 and 2011 and that developed social activities. Using the year 2006 as a starting point, we performed simple random sampling from the population of franchises for that year. In subsequent years, we maintained the same franchises as those chosen for 2006-eliminating any that had since been rolled up-and added new franchises to ensure the representativeness of the sample for each of the six years under study.

Table 1 presents a summary of the variables-definition, nomenclature, and their metrics-that feature in the model below.

\section{Findings}

Table 2 shows the descriptive statistics for the variables described in Table 1.

In addition to the univariate analysis, we performed a bivariate analysis with the aim of uncovering the multiple correlation between the independent variables, thereby evaluating the model's collinearity. Table 3 shows that all Variance Inflation Factors (VIF) values are below 10 and that the tolerance values all indicate that collinearity explains a maximum of $10 \%$ of the variance of any independent variable.

The linear regression model that we aim to estimate to explain the relationship between franchise 
Table 1. Variables and their metrics

\begin{tabular}{|c|c|c|}
\hline Variable Name & Metric & References \\
\hline \multicolumn{3}{|c|}{ Dependent Variable } \\
\hline [TEADO] Franchise choice & $\begin{array}{l}\% \text { of new franchised establishments opened by a first- } \\
\text { time franchisee. }\end{array}$ & Ehrmann and Spranger, 2005 \\
\hline \multicolumn{3}{|c|}{ Independent Variables } \\
\hline [LNG] Brand equity & $\begin{array}{l}\text { Number of years since the franchise began its } \\
\text { operations with respect to the observation year. }\end{array}$ & Windsperger and Dant, 2006 \\
\hline [INVI] Initial investment & $\begin{array}{l}\text { Amount (in euros) demanded by the franchisor, } \\
\text { excluding up-front entry fees. }\end{array}$ & \\
\hline [DE] Up-front entry fees & $\begin{array}{l}\text { Amount (in euros) that a franchisee must pay the } \\
\text { franchisor as a single, one-time payment. }\end{array}$ & Shane et al., 2006 \\
\hline$[\mathrm{RYT}]$ Royalties & $\%$ of sales that franchisees must pay the franchisor. & Kaufmann and Dant, 2001 \\
\hline [FSIF] Franchise fair (SIF\&CO) & $\begin{array}{l}\text { Participation in the SIF\&CO franchise fair. Dichotomous } \\
\text { variable that takes the value } 1 \text { if the franchise has } \\
\text { participated and } 0 \text { otherwise. }\end{array}$ & \\
\hline $\begin{array}{l}\text { [FEXPOF] Franchise fair } \\
\text { (ExpoFranquicia) }\end{array}$ & $\begin{array}{l}\text { Participation in the ExpoFranquicia franchise fair. } \\
\text { Dichotomous variable that takes the value } 1 \text { if the } \\
\text { franchise has participated and } 0 \text { otherwise. }\end{array}$ & Baena \& Cerviño, 2012 \\
\hline \multicolumn{3}{|c|}{ Control Variables } \\
\hline $\begin{array}{l}s=\text { Sector } \\
\text { (hostelry, retailing, and } \\
\text { services) }\end{array}$ & $\begin{array}{l}\text { Dummy variable that takes the value } 1 \text { if the chain } \\
\text { belongs to one of the three sectors included in the } \\
\text { study and } 0 \text { otherwise. }\end{array}$ & Michael, 2009 \\
\hline$d=$ Time & $\begin{array}{l}\text { Dummy variable that takes the value } 1 \text { for a given } \\
\text { period and } 0 \text { otherwise. }\end{array}$ & Shane et al., 2006 \\
\hline
\end{tabular}

signals and franchise choice by the franchisee is the following:

$\mathrm{TEADO}_{i t}=\dot{\alpha} n+\dot{\alpha} 1\left[\mathrm{LNG}_{i t}\right]-\dot{\alpha} 2\left[\mathrm{INVI}_{i t}\right]+\dot{\alpha} 3\left[\mathrm{DE}_{i t}\right]+$ $+\dot{\alpha} 4\left[\mathrm{RYT}_{i t}\right]+\dot{\alpha} 5\left[\mathrm{FSIF}_{i t}\right]+\dot{\alpha} 6\left[\mathrm{FEXPOF}_{i t}\right]+\eta i+\mathrm{d} t+$ $+\mathrm{si}+\mathrm{vit}$

The estimation of the model applies panel data methodology (using the Generalized Method of Moments (GMM) framework). We opt for this method to con- trol for the unobservable heterogeneity of the potential franchisee, such as his managerial talent or personal traits, and to correct for any possible endogeneity between the dependent and independent variables (Shane et al., 2006). Furthermore, this methodology allows us to include in the model the effects of certain macroeconomic variables that may influence potential franchisees' choice of franchise.

Table 4 shows the results of the estimate of the dynamic linear model upon introducing the one-period 
Table 2. Descriptive statistics for the sample

\begin{tabular}{lrrrr}
\hline Var. & Mean & S.D. & Min. & Max. \\
\hline TEADO & 0.02 & 0.03 & 0 & 0.08 \\
LNG & 13.95 & 8.37 & 0 & 71.00 \\
INVI & $121,947.80$ & $130,871.70$ & 0 & 2020.99 \\
DE & $15,155.43$ & $17,465.77$ & 0 & 300.00 \\
RYT & 0.03 & 0.04 & 0 & 0.60 \\
FSIF & 0.04 & 0.21 & 0 & 1.00 \\
FEXPOF & 0.05 & 0.22 & 0 & 1.00 \\
\hline
\end{tabular}

Table 3. Variance inflation factors and tolerance measures

\begin{tabular}{lcc}
\hline Variable & VIF & (1/VIF) \\
\hline LNG & 1.02 & 0.985 \\
INVI & 1.21 & 0.830 \\
DE & 1.31 & 0.765 \\
RYT & 1.10 & 0.909 \\
FSIF & 1.31 & 0.765 \\
FEXPOF & 1.32 & 0.757 \\
\hline Mean VIF & 1.21 & \\
\hline
\end{tabular}

lagged variable, [TEADO_1] as an explanatory variable. Inclusion of this variable is advisable, as a potential franchisees' choice may be influenced by his choices in the previous year.

\section{Conclusion}

The limited literature that exists is practice oriented, focusing upon the key managerial challenges faced by social entrepreneurs in franchising. The results fail to corroborate the hypothesis linking franchise choice to brand equity [H1], initial investment [H2], and royalties [H4]. The results do, however, corroborate hypothesis [H3], which posits a direct relationship between up-front entry fees and the franchisee's decision. According to our results, the relationship in [H3] is significant and positive when the model accounts for the time dummy variables. The results also corroborate, in all three estimates, hypothesis [H5], which links franchise choice to franchises' participation in franchise fairs.

In terms of the control variables, the effects of the macroeconomic variables, represented by the time dummy variables, seem to exert an influence on franchise choice, with a greater influence existing between 
Table 4. Estimates of the proposed model

\begin{tabular}{|c|c|c|c|}
\hline Var. & I & II & III \\
\hline TEADO $_{\mathrm{it}-} 1$ & $\begin{array}{c}-0.490^{* * *} \\
(0.000)\end{array}$ & $\begin{array}{c}-0.511^{* * *} \\
(0.000)\end{array}$ & $\begin{array}{c}-0.511^{* * *} \\
(0.000)\end{array}$ \\
\hline $\mathrm{LNG}_{\mathrm{it}}$ & $\begin{array}{c}-0.009^{* * *} \\
(0.000)\end{array}$ & $\begin{array}{l}-0.013^{*} \\
(0.005)\end{array}$ & $\begin{array}{c}-0.013^{*} \\
(0.005)\end{array}$ \\
\hline$|N V|_{i t}$ & $\begin{array}{l}-3.790 \\
(0.025)\end{array}$ & $\begin{array}{c}5.260 \\
(0.031)\end{array}$ & $\begin{array}{c}5.260 \\
(0.031)\end{array}$ \\
\hline$D E_{i t}$ & $\begin{array}{l}-6.880 \\
(0.661)\end{array}$ & $\begin{array}{l}6.200^{*} \\
(0.002)\end{array}$ & $\begin{array}{l}6.200^{*} \\
(0.002)\end{array}$ \\
\hline $\mathrm{RYT}_{\mathrm{it}}$ & $\begin{array}{c}-0.063^{* * *} \\
(0.000)\end{array}$ & $\begin{array}{l}-0.140^{* * *} \\
(0.000)\end{array}$ & $\begin{array}{l}-0.140^{* * *} \\
(0.000)\end{array}$ \\
\hline $\mathrm{FSIF}_{\text {it }}$ & $\begin{array}{l}0.004^{*} \\
(0.044)\end{array}$ & $\begin{array}{c}-0.013^{*} \\
(0.005)\end{array}$ & $\begin{array}{l}-0.013^{*} \\
(0.005)\end{array}$ \\
\hline FEXPOF $_{\text {it }}$ & $\begin{array}{c}0.030^{* * *} \\
(0.000)\end{array}$ & $\begin{array}{c}0.044^{* * *} \\
(0.000)\end{array}$ & $\begin{array}{c}0.044^{* * *} \\
(0.000)\end{array}$ \\
\hline V.Temp. & -.-- & Deleted 2/6 & Deleted 2/6 \\
\hline$Z_{1}$ & $\begin{array}{c}76.69(7) \\
(0.000)\end{array}$ & -- & --_-- \\
\hline$Z_{2}$ & 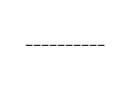 & $\begin{array}{c}18.91(4) \\
(0.000)\end{array}$ & $\begin{array}{c}18.91(4) \\
(0.000)\end{array}$ \\
\hline$m_{1}$ & 0.000 & 0.000 & 0.000 \\
\hline$m_{2}$ & 0.000 & 0.000 & 0.000 \\
\hline Hansen & 0.220 & 0.810 & 0.810 \\
\hline Obs. & 310 & 310 & 310 \\
\hline Chains & 166 & 166 & 166 \\
\hline
\end{tabular}

2008 and 2011. Moreover, the decisions from previous periods appear to have a negative effect on the current choice of franchise, as shown by the role of the lagged variable. Finally, franchises from the same sector do not compete with one another for franchisees-the quality of the chains in all sectors follows a continuous distribution. Consequently, evidence is lacking as to the dif- ferences in quality between chains, which means that sector is inadequate as a signal (Cheong \& Kim, 2004).

In conclusion, potential franchisees seek information about the quality of franchises with which they are looking to enter into business through direct signals such as participation in franchise fairs. This is because these signals allow potential franchisees to gain 
knowledge directly from franchisors about new business concepts, as well as to obtain the information they are searching for. Beckmann and Zeyen (2014) noted that the idea of friendchising (friendship between the franchisor and the franchisees) is misleading in social franchising because in a complex social franchise system, there is too little contact and too little transparency. Therefore, direct marketing, mainly in the form of participation in franchise fairs, emerges as a potent information signal (Perrigot et al., 2011) that potential franchisees regard as important in their decision-making process. Up-front entry fees also constitute a signal that potential franchisees consider, particularly when macroeconomic variables are exerting a strong influence on these individuals.

It is noteworthy that the managerial implications of the study are that franchise chains seeking franchisees should participate in franchise fairs to ensure that they are among the chosen franchises. Additionally, a franchisor should appropriately manage up-front entry fees as a signal, especially when the potential franchisee is affected by macroeconomic variables, as is the case during periods of economic turmoil and recession.

Future research should use qualitative comparative analysis for this type of study. This would help in gaining an understanding of both the franchisor and franchisee perspective.

\section{References}

Baena, V., \& Cervino, J. (2012). International franchise expansion of service chains: Insights from the Spanish market. Service Industries Journal, 32(7), 1121-1136.

Beckmann, M., \& Zeyen, A. (2014). Franchising as a strategy for combining small and large group advantages (logics) in social entrepreneurship: A Hayekian perspective. Nonprofit and Voluntary Sector Quarterly, 43(3), 502-522.

Bennett, S., Frazer, L., \& Weaven, S. (2010). What prospective franchisees are seeking. Journal of Marketing Channels, 17(1), 69-87.

Blythe, J. ( 2010). Trade fairs as communication: A new model. Journal of Business \& Industrial Marketing, 25(1), 57-62.

Cheong, I., \& Kim, J. Y. (2004). Costly information disclosure in oligopoly. Journal of Industrial Economics, 52(1), 121-132.
Dant, R. P., \& Kaufmann, P. J. (2003). Structural and strategic dynamics in franchising, Journal of Retailing, 79(2), 63-75.

Ehrmann, T., \& Spranger, T. (2005). Why do franchisors combine franchises and company-owned units? Social Science Research Net Work, Available at http://papers.ssrn.com/sol3/papers.cfm?abstract_ $\mathrm{id}=807346$

Fadairo, M. (2013).Why include royalties in distribution contracts? Evidence from France. International Journal of Retail \& Distribution Management, 41(8), 566-583.

Grace, D., \& Weaven, S. (2011). An empirical analysis of franchisee value-in-use, investment risk and relation satisfaction. Journal of Retail, 87(3), 366-380.

Guilloux, V., Gauzente, C., Kalika, M., \& Dubost, N. (2004). How France's potential franchisees reach their decisions: A comparison with franchiser's perceptions. Journal of Small Business Management, 42(2), 218-224.

Janney, J. J., \& Folta, T. B. (2006). Moderating effects of investor experience on the signalling value of private equity placements. Journal of Business Venturing, 21(1), 27-44.

Kaufmann, P. J., \& Dant, R. P. (2001). The pricing of franchise rights. Journal of Retailing, 77(4), 537-45.

Mariz, R., \& García, T. (2009). The internalization strategy of Spanish indigenous franchised chains: A resource-based view. Journal of Small Business Management, 47(4), 514-530.

Michael, S. C. (2009). Entrepreneurial signalling to attract resources: The case of franchising. Managerial and Decision Economics, 30(6), 405-422.

Perrigot, R., Basset, G., \& Chiquet, G. (2011). Multichannel communication: The case of Subway attracting new franchisees in France. International Journal of Retail \& Distribution Management, 39(6) 434-455.

Shane, S., Shankar, V., \& Aravindakshan, A. (2006). The effects of new franchisor partnering strategies on franchise system size. Management Science, 52(5), 773 - 787.

Tracey, P., \& Jarvis, O. (2007). Toward a theory of social venture franchising. Entrepreneurship Theory and Practice, 31(5), 667-685. 
Weaven, S., \& Frazer, L. (2006). Investment incentives for single and multiple unit franchisees. Qualitative Market Research: An International Journal, 9(3), 225-242.

Windsperger, J., \& Dant, R. P. (2006). Contractibility and ownership redirection in franchising: A property rights view. Journal of Retailing, 82(3), 259-272.

Wu, L. (1999). The pricing of a brand name product: Franchising in the motel services industry. Journal of Business Venturing, 14(1), 87-102.

Xavier, S. R., Kelley, D., Kew, J., Herrington, M., \& Vorderwülbecke, A. (2012). 2012 Global Report. Global Entrepreneurship Monitor. Retrieved from http://www.gemconsortium.org/report 